\title{
A STUDY OF RESEARCH SKILLS OF KOSOVAR STUDENTS: AN ASSESSMENT OF THE INFLUENCE OF INCLUSION, EXCLUSION, ETHNICITY, PA- RENTAL EDUCATION AND GENDER
}

\author{
ARIF SHALA \\ Institute for Professional Development Prishtina \\ AAB College, Rr. "Elez Berisha", nr. 56, \\ Zona Industriale Prishtinë - Fushë Kosovë, 10000 Prishtinë, \\ Republika e Kosovës \\ E-mail: shala.arif@pdi-ks.org \\ ORCID: https:/ / orcid.org/0000-0002-6605-0532

\section{ALBULENE GRAJCEVCI} \\ Institute for Professional Development Prishtina \\ Albulene Grajcevci, University of Mitrovica "Isa Boletini", \\ Rr. Ukshin Kovacica, 40000 Mitrovice, Republika e Kosovës \\ E-mail: grajcevci.albulene@pdi-ks.org \\ ORCID: https://orcid.org/0000-0002-5697-3691
}

\begin{abstract}
Aim. The aim of the current study is to address a gap in literature as well as explore the factors influencing the perceptions that Kosovar students hold over their research skills. To that end, the study assessed students' perception of their research abilities as well as the variables which influence this perception, namely inclusion, exclusion, ethnicity, gender and parental education.

Methods. The study employed the quantitative research approach. 303 Kosovar university students participated in the study by answering an instrument composed of three different scales measuring the variables in the study, namely the research skills scale, inclusion scale and exclusion scale. In addition the participants answered ten demographic questions. Participats volunteered for the study and the results were analyzed with SPSS package.

Results. Participants in this study reported the highest levels of research skills when they also reported being included in academic settings. Ethnicity was a powerful influencing variable. Participants who belonged to minority groups were the ones to report the lowest levels of abilities. Contrary to existing literature, gender did not influence perceptions on abilities. Additionally, inconsistently with a vast number of research studies, parental education did not influence perceptions that Kosovar students held over their research skills.
\end{abstract}


Conclusions. This study is the first one to research skill acquisition among student populations in Kosovo, a region that is almost absent in international literature. This research presents an overview of variables predicting perceptions held by Kosovar students of their research skills with ethnicity and inclusion being detrimental to their perceptions of research skills.

Key words: Research skills, parental education, inclusion, exclusion, Kosovo.

\section{INTRODUCTION}

$\mathrm{T}$ The interest in educational research arguably results from the shift from production societies to service-providing societies, alongside globalisation trends and developments in technology. Recently, interest in education has been sparked again but this time due to its economic implications. A number of researchers argue that education is the factor that mostly influences economic growth (Benos, \& Zotou, 2014). Evidently, scholars agree on two mechanisms through which education exerts influence on economic growth. Firstly, education enhances the human capital which increases labour productivity, ultimately increasing output. Secondly, education is argued to make societies as a whole more innovative while also increasing innovation in respect to products and process. Hence, the importance of education is embedded in its ability to create the prerequisites for sustainable development by providing generations with mental models and conceptual toolboxes which determine goals, attitudes and aspirations (Tillbury, 2007).

Recently, a shift from traditional concepts of education to the new notion of the $21^{\text {st }}$ century skills has become evident. The learning outcomes of the $21^{\text {st }}$ century refer to knowledge and expertise necessary to succeed in life and work. EnGauge (NCREL, 2003) maintains that the $21^{\text {st }}$ century skills include the following: digital age literacy, inventive thinking, effective communication and high productivity. Studies report that countries which document low levels of the skills are less competitive in the world economy. The new era has subjected countries to a number of challenges including but not limited to globalisation, internationalisation and advances in information and communication technologies. Due to these developments, education systems have been strained to provide students with the $21^{\text {st }}$ century skills that would enable graduates to operate in the new era (Soh, Osman, \& Arsad, 2012). Literature suggests that the $21^{\text {st }}$ century demands skills such as critical thinking (e.g., Bowles, 2000; Williams, \& Stockdale, 2003; Jonassen, 2011); computer literacy (e.g., Pennings, 2001) and effective communication (e.g., Habaci, Habaci, Adigüzelli, \& Kurt, 2003).

The topic of the $21^{\text {st }}$ century skills is of particular importance to the countries that have human capital as their only viable resource. Kosovo is a country located in Southeastern Europe with a population of 1.7 million inhabitants. The country established its independence only in 2008 and has ever since been subject to major changes not only in the political sphere but in every domain. Evidently, the country has been subjected to swift changes in the government 
and overall instability. The country is primarily inhabited by young people and it is considered to be the youngest country in Europe. To that end, this study provides valuable data as it addresses a key factor for economic prosperity, namely development of human resources. Building on existing research, the present study will assess research skills as a component of $21^{\text {st }}$ century skills across education institutions in Kosovo. In addition, the research focuses on variables which influence perceptions of research abilities, such as inclusion, exclusion, ethnicity, parental education and gender.

\section{LITERATURE REVIEW}

The concept of $21^{\text {st }}$ century skills is a rather new notion in research. In the 21st century, countries are exposed to a variety of challenges including the expansion of information and communication technology, globalisation and internationalisation. These developments have put pressure on education systems to train students with the $21^{\text {st }}$ century skills that would enable graduates to operate in the new era (Soh, Osman, \& Arsad, 2012). EnGauge (NCREL, 2003) maintains that $21^{\text {st }}$ century skills include the following: digital age literacy, inventive thinking, effective communication and high productivity. As a result a $21^{\text {st }}$ century graduate is expected to possess a variety of skills -in addition to specific major skills - including but not limited to literacy, numeracy and problem solving, self-management, interpersonal communication and the skills of lifelong learning, if they are to survive the changing nature of our societies (OECD, 2013). By relying on the existing studies, this research focuses on assessing one type of $21^{\text {st }}$ century skills among students in Kosovo, namely research skills.

Present research expects parental education to be a powerful influence on the perceptions that participants hold over their abilities. The correlated disadvantage model (Haverman, \& Wolfe, 1995) postulates that low parental education, low social resources and chaotic lives determine the capital development of children (Haverman, \& Wolfe, 1995; Mayer, 1997; Wickrama, Conger, Lorenz, \& Jung, 2008). A considerable number of studies support the hypothesis that mother's education and occupation status considerably influence the educational achievements of their sons and daughters (Korupp, Ganzeboom, \& Derlippe, 2002). The education of parents is positively linked to educational attainment of their children (Mangione, \& Speth 1998; Mayer, 1997; Scott-Jones, 1995). In the studies where parental income was controlled for the educational level of parents determined socioeconomic achievements in adults (Haverman, \& Wolfe, 1995). Children whose parents have higher aspirations tend to perform better (Dickensheets, 1996).

The second variable that influences the acquisition of research skills is inclusion in education. The definition of inclusive education tends to vary according to nations (Artiles, Kozleski, \& Waitoller, 2011), schools (Ainscow, Booth, \& Dyson, 2006), and the research orientation (Artiles, Harris-Murri, \& Rosten- 
berg, 2006). In educational settings, social inclusion is understood as the problems faced by special groups who have limited or no access to school; examples of these groups most often include minority groups. However, students coming from economically poor families and communities face the threat of exclusion as well, regardless of belonging or not belonging to minority groups (Miles, \& Ainscow, 2008).

Inclusive education is the global initiative responding to the exclusion of students by education systems despite differences among those students. Excluding students because they are different (e.g. poor students) is not a new concept, it is rather the tendency to limit access and participation in education to specific groups of students (Waitoller \& J, 2013). One of the reasons for this exclusion is the fact that these groups are generally prone to severe economic conditions. The economic resource model suggests that limited economic resources of parents influence socioeconomic difficulties (Becker, 1981, 1993). First, parents who have limited resources must allocate them between basic needs and education (Becker, 1993; Corcoran 1999). Additionally, poor parents tend to live in communities which lack resources (Coleman, 1990; Jencks \& Mayer, 1990). Studies have documented that difficult circumstances (Brooks-Gunn, Duncan, Klebanov, \& Sealand, 1993; Elliot, Menar, Rankin, Elliot, Wilson, \& Huizinga, 2006; Leventhal \& Brooks-Gunn, 2000), one parent families (Simons, 1996), economic disadvantages (Conger Conger \& Martin, 2010) are likely to bear negative influence on the development of children. The study of Gore and Aseltine (2003), similarly to other studies, discovered that the income of parents predicted the achievement of young adults. The results of the study were consistent with the hypothesis that low-income parents do not have the means to support the development of children. Furthermore, studies also showed that the adolescents coming from disadvantaged families tend to be unsuccessful in school in addition to having low social skills and weak links to the community (Wickrama, Simons \& Baltimore, 2012).

In Kosovo, inclusive education remains a challenge as the educational situation of Roma community is rather desperate. About $75 \%$ of Roma attend primary education, but the rate drops in relation to attending secondary or university education. Ministry of Education, Science and Technology (MEST) reports that only 204 Roma students are attending secondary or university education, which may also reflect low graduation rates among this community, which are reported to be $1.4 \%$. Evidently, exclusion from the educational system remains a problem for ethnic minorities and low-income groups. While some action has been taken to include marginalised groups in educational systems, much remains to be done for minority groups (Gentilini, 2009). Unfortunately, limited inclusion measures have been employed for areas characterised by poor minority groups, and regardless of low educational participation and attainment, much remains to be done in including them in the educational system (Barrientos, 2011). Considering existing research on the link between 
inclusion and academic achievement, present research stipulates that in developing countries such as Kosovo, inclusion is a significant predictor of ability levels reported by students. To that end, it is expected that students who are included will report the highest levels of research abilities while students who are excluded will report the lowest.

\section{METHODOLOGY AND MEASUREMENTS}

\section{Participants}

University students across Kosovo represent the sample of this study. The instrument was uploaded online and translated to Albanian. At this point, it is important to clarify that the instrument went through the back to back translation procedure before being utilised for the purposes of the study. The author of the study disseminated the link to the instrument along with the description of the study among all coordinators at universities, and it is these coordinators that further distributed the instrument among students via email. 303 participants filled out the survey over the period of 11 weeks.

The study attracted more female than male students, with the sample of $54 \%(\mathrm{~N}=163)$ female students and $46 \%(\mathrm{~N}=140)$ male students. The mean age for the participants was $\mathrm{M}=24.37(S D=5.24)$, however for the purposes of this study, the participants were grouped in certain age ranges. As such, 48 participants were younger than 20 years old, 176 participants reported being between 21 and 25 years old, another 62 participants were between 26 and 30 years old, and 16 participants were between 31 and 40 yours old. Finally, the 7 remaining participants were between 41 and $48(\mathrm{~N}=5)$ and older than $49(\mathrm{~N}=2)$.

As expected, the majority of the participants in this study were between 21 and 25 years old (58\%). Another significant percentage was the 26 to 30 participants, who constituted $20 \%$ of the sample. In this study, $15 \%$ of the participants reported being 20 years old or younger. Since this study targeted students, it is no surprise that $94 \%$ of the participants in this study were 30 or younger. In general sense, the age range of 18 to 30 is when individuals usually pursue academic studies. The remaining participants were older than 30 , more specifically $5 \%$ reported being between 31 and 40 years old, $1 \%$ of the participants were 41 to 48 , and the very small percentage of less than one was older than 49.

Similarly to the age, the academic status of the participants varied as well. The majority of participants reported attending bachelor level studies 51\% $(\mathrm{N}=156)$. Another 105 participants $(34 \%)$ were attending master level studies at the time. A very small number of participants (less than one percent) reported attending PhD programs ( $\mathrm{N}=2)$. Ultimately, 40 participants $(13 \%)$ chose the option other to describe their education status and noted that they were attending professional Bachelor or Master Programs. 


\section{Research skills scale}

Academic research skills were measured by four items (e.g., I am content with my research skills). The table below (see Table 1) provides the descriptive statistics and the Cronbach Alpha value for the research skills scale. Results show that the value of Cronbach's Alpha is .70 which as a value is acceptable to signal reliability of the scale. Furthermore, standard deviation $(S D=.71)$ fulfills the criteria of parametric tests.

Table 1. Descriptive Statistics and Cronbach's Alpha for Measures of Research Skills

\begin{tabular}{lcccccc}
\hline Variable & $\begin{array}{c}\text { Cronbach's } \\
\text { Alpha }\end{array}$ & Mean & $S D$ & Range & Skewness & Kurtosis \\
\hline Research Skills & .70 & 3.70 & .71 & $1-5$ & -.55 & .64 \\
\hline
\end{tabular}

Note. $\mathrm{N}=303$.

\section{Inclusion}

The perception of inclusion was measured with 12 items, scored in a Likert scale ranging from 1 strongly disagree to 5 strongly agree. Five items were adopted from the Discrimination Hassles developed by Peter Titzmann, Silbereisen, Rainer Mesch and Eva Schmitt-Rodermund, (2011) (I was laughed at at school because of my ethnic background, I was teased by others because of my ethnic background, I was sworn at school because of my ethnic background, my classmates ignored me because of my ethnic background, and my classmates did not talk to me because of my ethnic background).

Additionally, four items were adapted from the Diversity, Individual Development, Differentiation survey (DIDDs). The original instrument was developed by Judy Lupart, Jessica Whitley, Janine Odishaw and Linda McDonald (2006). According to Lupart, Whitley, Odishaw and McDonald (2006), the survey included a number of concepts such as school culture, learning, teaching safety, student entitlement and the development of schools, and included 59 items. However, the present study chose only four items from the revised DIDDs developed by Loreman, McGhie-Richmond, Barber and Lupart in 2008. Loreman and colleagues (2008) developed the Student Perceptions of Inclusion in Rural Canada (SPIRC) scale. The present study utilized four items from the latter scale (I look forward to going to the university; Lots of times, I feel lonely at the university; I often stay by myself because other students refuse to interact with me; I am one of the last to be chosen for groups or team work at the university). In conclusion, the exclusion subscale was composed of 9 items and yielded an Alpha value of .94 which is a superb value. Furthermore, value of standard deviation was .89 , lower than 1 , so no violations of parametric tests occurred (please see the table below).

Finally, three items (I felt involved in developments within the university e.g. student union; Professors encouraged me to become involved in learning; I had opportunities to interact with professors within my university) were adapted from the Student Perception of Research Integration Questionnaire (SPRIQ) developed by 
Visser-Wijnveen, van der Rijst and van Driel (2015). The original questionnaire measured, among others, reflection, motivation, participation, quality, beliefs and current research. The initial scale was composed of 40 items, however, the present study utilized only 3 items in measuring perceptions of participation. Finally, the inclusion subscale included the items and had alpha value of .67 which although, lower than the value of exclusion subscale, still falls in the acceptable range. Ultimately, the standard deviation of this subscale was .80 , lower than the value of 1 , enabling thus the use of parametric tests (see Table 2).

Table 2. Descriptive Statistics and Cronbach's Alpha for Measures of Inclusion and Exclusion in Higher Education Institutions in Kosovo

\begin{tabular}{lcccccc}
\hline Variable & $\begin{array}{c}\text { Cronbach's } \\
\text { Alpha }\end{array}$ & Mean & $S D$ & Range & Skewness & Kurtosis \\
\hline Inclusion & .67 & 3.28 & .80 & $1-5$ & -.19 & -.29 \\
Exclusion & .94 & 1.84 & .89 & $1-5$ & 1.73 & 2.92 \\
\hline
\end{tabular}

Note. $\mathrm{N}=303$.

\section{RESULTS \& DISCUSSION}

Hypothesis 1 states that inclusion in academic settings will positively correlate to research skills of participants. Pearson correlation analysis was conducted to measure the link between inclusion and research skills. The results (see Table 3 ) document that there is a significant positive correlation between inclusion rates and research skills $(r(303)=.380, p<.01)$.

Table 3. Correlations between inclusion, exclusion and Research Skills

\begin{tabular}{lccc}
\hline Measure & 1 & 2 & 3 \\
\hline 1. Inclusion & - & & \\
2. Exclusion & $-.115^{*}$ & - & \\
3. Research Skills & $.380^{* *}$ & $-.251^{* *}$ & \\
\hline
\end{tabular}

Note: **. Correlation is significant at the 0.01 level (2-tailed).

Hypothesis 2 indicates that the exclusion from academic settings will negatively correlate to levels of research skills. Pearson correlation analysis was conducted to test if the link between exclusion and research skills was evident (see Table 3). As expected, exclusion was significantly positively correlated to research skills $(r(303)=-.251, p<.01)$.

Hypothesis 3 assumes that higher levels of education in mothers are linked to higher levels of research skills in students. A one-way independent ANOVA was conducted to compare the influence of the education of mothers in the Research skills of participants. There was a not significant influence of mother education in the perceptions of research skills in students $F(3,273)=1.38, p$ $=.24($ see Table 4$)$. 
Table 4. One-Way Analysis of Variance of Research Skills by Education of Mother, Education of Father, Socioeconomic Status, Ethnic Background and Type of Residence

\begin{tabular}{llll}
\hline Variable & $D f$ & $F$ & $p$ \\
\hline Education of Mother & 3 & 1.38 & .248 \\
Education of Father & 3 & 1.52 & .208 \\
Ethnic Background & 2 & 6.12 & .002 \\
\hline
\end{tabular}

Hypothesis 4 assumes that higher levels of education in fathers are linked to higher levels of research skills in students. A one-way independent ANOVA was conducted to compare the influence of the education of father in the research skills of participants. There was a not significant influence of father education in the perceptions of research skills in students $F(3,280)=1.52 p=.20$ (see Table 4).

Hypothesis 5 states that ethnic background influences research skills in participants because participants from minority groups will report lower research skills compared to students from majority groups who will report higher levels of research skills. A one-way independent ANOVA was conducted to compare the effect of the ethnic background on research skills of participants. There was a significant influence of the ethnic background on the perceptions of research skills in students $F(2.300)=6.12, p=.00$ with an effect size $r=.19$ (see Table 4). Students who belonged to the Roma, Ashkali and Egyptian community reported the lowest research skills $(M=3.40, S D=.71)$, followed by students who belonged to the majority group $(M=3.77, S D=.71)$. Finally, participants that belonged to other minority groups were the ones to report the highest research skills $(M=3.78, S D=.58)$. Post hoc analyses using the Hochberg's GT2 (very different sample sizes) post hoc criterion for significance indicated significant differences in research skills between students based on ethnic background of students with students who belong to the RAE community reporting significantly lower levels of research skills compared to students who belong to other groups.

Hypothesis 6 assumes that the levels of education of parents will predict levels of research abilities in participants with participants whose parents possess higher levels of education reporting higher levels of abilities in research. An independent factorial ANOVA was conducted to explore the influence of parents' education on perceptions of research skills in students. The results indicate that mother's education has no influence on research skills $F(3,303)=1.28, p>.05$, similar to father's education which did not influence perceptions that students held on their research abilities $F(3,303)=1.34, p>$ .05. Finally, a combination of parents' education levels also did not have a significant influence on levels of research skills in students $F(8,303)=.83, p$ $>$.05 (see Table 5). 
Table 5. Analysis of Variance for Research Skills by Education of Parents

\begin{tabular}{|l|l|l|l|l|l|l|}
\hline Dimension & SS & df & MS & F & p & Partial n2 \\
\hline Mother's Education & 1.874 & 3 & .625 & 1.287 & .279 & .015 \\
\hline Father's Education & 1.952 & 3 & .651 & 1.340 & .262 & .016 \\
\hline $\begin{array}{l}\text { F a th e r * M o t h e r } \\
\text { Education }\end{array}$ & 3.233 & 8 & .404 & .832 & .575 & .025 \\
\hline
\end{tabular}

Hypothesis 7 states that there is a gender influence in the levels of research skills in students with female students reporting lower research abilities compared to males students. An independent t-test was conducted to measure the influence of gender on perceptions of Research skills. The results provided that there was no significant influence of gender on research skills $t(301)=-1.51$, $p=.12$. Nevertheless, the data suggests that there is a difference between genders as male students reported higher perceptions of research skills $(M=3.77$, $S D=.62)$ compared to female students who reported lower research skills $(M=3.65, S D=.78)$.

\section{PREDICTORS OF RESEARCH SKILLS}

A multiple regression analysis with 2 predictive variables was conducted to predict perceptions of research skills held by participants. The variables were divided in two models. In Model 1 inclusion was a strong predictor of perceptions in participants $R^{2}=.14, F(1,303)=50.94, p<.01$ accounting for $38 \%$ of variance in perception levels $(\beta=.38)$. In model 2 , exclusion was added and both variables significantly predicted perceptions of research skills $R^{2}=.18, F(2,303)$ $=34.79, p<.01$, with inclusion predicting $35 \%(\beta=.35)$ and exclusion predicting $21 \%(\beta=-.21)$ of the variance in perceptions of research abilities (see Table 6).

Table 6. Summary of Hierarchical Regression Analysis for Variables Research Skills

\begin{tabular}{lll}
\hline & Model 1 & Model 2 \\
\hline Variable & $B S E(B) \beta$ & $B S E(B) \beta$ \\
\hline Inclusion & $.34 .04 .38^{* *}$ & $.31 .04 .35^{* *}$ \\
Exclusion & & $-.16 .04-.21^{* *}$ \\
$R^{2}$ & .14 & .18 \\
$F$ for change in $R^{2}$ & $50.94^{* *}$ & $34.79^{* *}$ \\
\hline
\end{tabular}

Note: ${ }^{*} p<.05 .{ }^{* *} p<.01$.

According to available data, an evident challenge faced by the education institutions in Kosovo is the integration of Roma and children with disabilities into the education system. Enrolment of these students remains largely unaddressed while attendance of other groups is largely determined by the poverty level as well as location, rural versus urban. In line with existing literature, the present study reported that inclusion in education settings was positively correlated to higher levels of perceptions on abilities and exclusion correlated 
negatively to skill perceptions. These findings suggest that in the future, academic settings across Kosovo should do more to foster the involvement of all students in the learning experience. Failure to do so will result in students not mastering skills and the economy being supplied with a labour force that lacks the necessary skills of the new era. Similarly, present research documented that ethnic background is an influential factor in skill acquisition, with minority groups reporting lower skills learned in academic settings. The exclusion of these groups from the education system limits them from contributing to the economy and simultaneously enables the poverty cycle to continue.

Finally, this study observed that female students reported lower skills compared to male participants. This finding implies that across students in Kosovo, females are more likely to underestimate their abilities which in turn may negatively influence their academic prospects. Additionally, it was unexpected to discover that parental education levels did not link to reported levels of abilities by participants. This finding goes contrary to existing literature which continuously reports a correlation between abilities and parents' education levels.

\section{CONCLUSION}

Human capital is considered to be the wealth found in skills, knowledge, and work (OECD, 2001). It is any form of knowledge that a person has which influences their economic productivity (Garibaldi, 2006). The essential argument of the human capital theory is that education enhances productivity and income and is a form of investment (Hornbeck \& Salamon, 1991) and to the value of investing in skill development (Blaug, 1970). The link between human capital and economic growth becomes even more crucial for countries such as Kosovo. The economy of Kosovo is growing slower than that of the other countries in the region: in 2009 Kosovo had 1,731 Euros in GDP per capita, and the GDP growth was 3.8\% (World Bank, 2010). Kosovo aims to establish an educational system that is adaptable to the needs and expectations of the society. Economic and social development should consider education an integral part of the strategy in the long term (MASHT, 2004). The Kosovo curriculum framework emphasises competences and outcomes, in particular being focused on the crucial competences, including but not limited to problem solving, ability to work in teams and communication skills (Van-Meel, 2010).

Present research found strong support for the link between inclusion and ability levels reported by students, more specifically students who were included in education settings reported the highest levels of skills. Consequently, students who reported feeling excluded from academic settings reported the lowest levels of research skills. To that end, both variables were strong predictors of reported abilities. These findings suggest that despite the need for thorough reforms in the education system, it is of critical importance that schooling opportunities for vulnerable groups are made available as this leads to social inclusion in the medium and long term (Kaufman, Kraay, \& 
Mastruzzi, 2004); this matter can no longer be left unaddressed. Therefore, making education accessible to all groups of the population is crucial. In the cases where education is not equally distributed, negative influences will be visible in per capita income (Ozturk, 2001).

In conclusion, this study is of particular importance since it provides data from a country that is not represented in international research. A second reason why this study has significant importance is that it is the first to research $21^{\text {st }}$ century skills among student populations in Kosovo. In conclusion, the data of this study will prove to be of importance to policy builders in Kosovo, in particular the data provided on the variables which hinder skill acquisition.

\section{REFERENCES}

[1] Ainscow, M., \& Miles, S. (2008). Making Education for All inclusive: Where next? Prospects, 38(1), 15-34.

[2] Ainscow, M., Booth, T., \& Dyson, A. (2006). Inclusion and the standards agenda: negotiating policy pressures in England. International Journal of Inclusive Education, 10, 295-308.

[3] Artiles, A., Kozleski, E. B., \& Gonzalez, T. (2011). Beyond the allure of inclusive education in the United States: Facing difficult questions, tracing enduring challenges. Revista Teias. 12, 24 285-308. Retrieved from: http:/ / www.periodicos.proped.pro.br/index.php?journal=revistat eias\&page $=$ article\&op $=$ view $\&$ path $\% 5 B \% 5 \mathrm{D}=820$

[4] Artiles, A. J., Harris-Murri, N., \& Rostenberg, D. (2006). Inclusion as social justice: Critical notes on discourses, assumptions, and the road ahead. Theory Into Practice, 45(3), 260-268.

[5] Barrientos, A. (2011). Social Protection and Poverty. International Journal of Social Welfare,20 (30), 240-249.

[6] Becker, G. (1981). A treatise on the family. Cambridge, MA: Harvard University Press.

[7] Becker, G. (1993). Human capital: A theoretical and empirical analysis with special reference to education. New York, NY: Columbia Press.

[8] Bentos, N. and Zotou, S. ( 2014). Education and Economic Growth: A Meta-Regression Analysis. World Development, 64 (C), 669-689.

[9] Blaug, M. (1970). An introduction to the economics of education. London: Penguin.

[10] Bowles, K. (2000). The relationship of critical-thinking skills and the clinical-judgment skills of baccalaureate nursing students. Journal of Nursing Education, 39, 373-376.

[11] Brooks-Gunn, J., Duncan, G., Klebanov, P., \& Sealand, N. (1993). Do neighborhoods influence child and adolescent development? American Journal of Sociology, 99, 353-395.

[12] Coleman, J. S. (1990). Foundations of social theory. Cambridge, MA: Harvard University Press.

[13] Conger, R., Conger, K., \& Martin, M. (2010). Socioeconomic status, family processes, and individual development. Journal of Marriage and Family, 72, 685-704.

[14] Corcoran, M. (1999). The economic progress of African-American women. In I. Browne (Ed.), Latinas and African American women at work: Race, gender, and economic inequality. Thousand Oaks, CA: Sage.

[15] Dickensheets, T. (1996). The role of the education Mama. Japan Quarterly, 43, 73-79.

[16] Elliot, D., Menard, S., Rankin, B., Elliot, A., Wilson, W., \& Huizinga, D. (2006). Good kids from bad neighborhoods. Cambridge, MA: Cambridge University Press.

[17] Garibaldi, P. (2006). Personnel economics in imperfect labor markets. Oxford, England: Oxford Press.

[18] Gentilini, U. (2009). Social Protection in the Real World: Issues, Models and Challenges. Development Policy Review, 27 (2), 147-166.

[19] Gore, S., \& Aseltine, R., Jr. (2003). Race and ethnic differences in depressed mood following the transition from high school. Journal of Health and Social Behavior, 44, 370-389.

[20] Habaci, I., Celik, E., Habaci, M., Adigüzelli, \& Kurt, S. (2013). Effective communication in Educational Administration. US-Cina Education Review, 3 (9), 690-702. 
[21] Haverman, R., \& Wolfe, B. (1995). Succeeding generations: On the effects of investments in children. New York, NY: Russell Sage Foundation.

[22] Hornbeck, D.W., \& Salamon, L. M. (Eds.). (1991). Human capital and America's future: An economic strategy for the nineties. Baltimore: Johns Hopkins University.

[23] Jencks, C., \& Mayer, S. (1990). The social consequences of growing up in a poor neighborhood. In L. Lynn \& M. McGeary (Eds.), Inner-city poverty in the United States. (pp. 111-186). Washington, DC: National Academy Press.

[24] Jonassen, D. H. (2011). New Educational Paradigm for Learning and Instruction. International conference on Education Research, Missouri, USA.

[25] Kaufman, D., Kraay, A., Mastruzzi, M., (2004). Governance matters III: governance indicators for 1996, 1998, 2000, and 2002. World Bank Economic Review 18, 253-287.

[26] Korupp, S. E., Ganzeboom, H. B., \& Derlippe, T. (2002). Do Mothers Matter? A Comparison of Models of the Influence of Mothers and Fathers Educational and Occupational Status on Childrens Educational Attainment. Kluwer, 36, 17-42.

[27] Leventhal, T., \& Brooks-Gunn, J. (2000). The neighborhoods they live in: The effects of neighborhood residence upon child and adolescent outcomes. Psychological Bulletin, 126, 309-337.

[28] Loreman, T., McGhie-Richmond, D., Barber, J., \& Lupart, J. (2008). Student Perspectives on Inclusive Education: A Survey of Grade 3-6 Children in Rural Alberta, Canada. International Journal of Whole Schooling, 5(1), 1-12.

[29] Lupart, J.L., Whitley, J., Odishaw, J., \& McDonald, L. (2006). Whole school evaluation inclusion: How elementary school participants perceive their learning community. In C. Dionne \& N. Rousseau (Eds.). Transformation of educational practices: Research on inclusive education (pp. 113-143). Quebec: Presses de l'Universite du Quebec.

[30] Mangione, P. L., \& Speth, T. (1998). The transition to elementary school: A framework for creating early childhood continuity through home, school, and community partnership. The Elementary School Journal, 98, 381-397.

[31] MASHT. (2004). Strategy for te Development of Higher Education in Kosova. Prishtine: Ministry of Education, Science and Technology.

[32] Mayer, S. E. (1997). What money can't buy: Family income and children's life chances. Cambridge, MA: Harvard University Press.

[33] Miles, S., \& Ainscow, M. (2008). Making Education for All Inclusive: Where Next. Prospects, 38(1), 15-34.

[34] NCREL, \& Metiri Group. (2003). enGauge 21st century skills: Literacy in the digital age. Napierville, IL and Los Angeles, CA: NCREL and Metiri.

[35] OECD. (2013). OECD Skills Outlook 2013: First Results from the Survey of Adult Skills, OECD Publishing. Retrieved from: http://dx.doi.org/10.1787/9789264204256-en

[36] OECD. (2001). Glossary of statistical terms. Retrieved from http://stats.oecd.org/glossary/ detail.asp?ID $=1264$

[37] Ozturk, I. (2001). The Role of Education in Economic Development: A Theoretical Perspective. Journal of Rural Development and Administration, XXXIII, (1), 37-49.

[38] Pennings, R. (2001, July). University of Wisconsin. Retrieved January 3, 2016, from University of Wisconsin: http://citeseerx.ist.psu.edu/viewdoc/ download?doi=10.1.1.391.4151\&rep=rep1\&type=pdf

[39] Simons, R. (1996). Understanding the differences between divorced and intact families: Stress, interaction, and child outcomes. Thousand Oaks, CA: Sage.

[40] Scott-Jones, D. (1995). Parent-child interactions and school achievement. In B. A. Ryan, G. R. Adams, T. P. Gullotta, R. P. Weissberg, \& R. L. Hampton (Eds.), The family-school connection: Theory, research, and practice (pp. 75-107). Thousand Oaks, CA: SAGE Publications, Inc.

[41] Soh, T. M. T., Osman, K., \& Arsad, N. M. (2012). M-21CSI: A Validated 21st Century Skills Instrument for Secondary Science Students. Asian Social Science, 8 (16), 38-44.

[42] Tillbury, D. (2007). Learning Based Change for Sustainability: Perspectives and Pathways . In A. E. Wals, Social Learning Towards a Sustainable World (pp. 117-132). Wageningen: Wageningen Academic Publishers.

[43] Titzmann, P. F., Silbereisen, R. K., Mesch, G. S., \& Schmitt-Rodermund, E. (2011). Migration-Specific Hassles Among Adolescent Immigrants From the Former Soviet Union in Germany and Israel. Journal of Cross-Cultural Psychology, 42(5), 777-794. 
Journal of Education Culture and Society No. 1_2019

[44] Van-Meel, R. (2010). Education and Business. Prshtine: European Training Foundation.

[45] Visser-Wijnveen, G. J., van der Rijst, R. M., \& van Driel, J. H. (2015) A questionnaire to capture students' perceptions of research integration in their courses. Higher Education, 71, (4), 473-488.

[46] Waitoller, F. R., \& J, A. A. (2013). A Decade of Professional Development Research for Inclusive Education: A Critical Review and Notes for a Research Program. Review of Educational Research, 83 (3), 319-356.

[47] Wickrama, K., \& Bryant, C. (2003). Community context of social resources and adolescent mental health. Journal of Marriage and Family, 65, 850-866.

[48] Wickrama, K., Conger, R., Lorenz, F., \& Jung, T. (2008). Family antecedents and consequences of trajectories of depressive symptoms from adolescence to young adulthood: A life course investigation. Journal of Health and Social Behavior, 49, 468-483.

[49] Wickrama, K.A., Simons L.G., Baltimore, D. (2012). The Influence of Ethnicity and Adverse Life Experiences During Adolescence on Young Adult Socioeconomic Attainment: The Moderating Role of Education. Youth Adolescence, 41(11), 1-16.

[50] Williams, R. L., \& Stockdale, S. L. (2003). High-performing students with low critical thinking skills. Journal of General Education, 52, 199-225.

[51] World Bank, Kosovo: Country brief (2010). World Bank, Washington DC, Retrieved from: http:// web.worldbank.org/WBSITE/EXTERNAL/COUNTRIES/ECAEXT/KOSOVOEXTN/0,,c ontentMDK:20629286 menuPK:297777 pagePK:141137 piPK:141127 theSitePK:297770,00. html\#econ 